\title{
Analysing and Comparing the Final Grade in Mathematics by Linear Regression Using Excel and SPSS
}

\author{
Elena Karamazova ${ }^{\# 1}$, Teuta Jusufi Zenku ${ }^{* 2}$, Zoran Trifunov ${ }^{\# 3}$ \\ ${ }^{1}$ Faculty of Computer Sciences Department of Mathematics and Statistics University "Goce Delcev" - Stip \\ Republic of Macedonia \\ ${ }^{2}$ Faculty of Technical Sciences University "Mother Teresa" - Skopje 1000 Skopje, Republic of Macedonia \\ ${ }^{3}$ Faculty of Technical Sciences University "Mother Teresa" - Skopje 1000 Skopje, Republic of Macedonia
}

\begin{abstract}
In this paper simple and multiple linear regression model is developed to analyze and compare the final grades of students from two Universities, University "Goce Delcev" - Stip, more specifically a group of students who studied in Kavadarci and students from "Mother Teresa" University in Skopje, for the subject of Mathematics. The models were based on the data of students' scores in three tests, 1st periodical exam, 2nd periodical exam and final examination. Statistical significance of the relationship between the variables has been provided. For obtaining our results some solvers like Excel and SPSS were used.
\end{abstract}

Keywords: simple linear regression, multiple linear regression, 1 st periodical exam, 2nd periodical exam, final examination.

\section{INTRODUCTION}

Simple linear regression is a statistical method that allows us to summarize and study relationships between two continuous variables: one variable, denoted $\mathrm{x}$, is regarded as the predictor, explanatory, or independent variable. The other variable, denoted $y$, is regarded as the response, outcome, or dependent variable.

Multiple linear regression can be used to analyze data from causal-comparative, correlational, or experimental research. In addition, it provides estimates both of the magnitude and statistical significance of relationships between variables.

Multiple linear regression is one of the most widely used statistical techniques in educational research.

Multiple linear regression is defined as a multivariate technique for determining the correlation between a response variable $\mathrm{y}$ and some combination of two or more predictor variables, $\mathrm{X}$.

In [11], such a model is developed to predict anomalies of westward-moving intraseasonal precipitable water by utilizing the first through fourth powers of a time series of outgoing longwave radiation that is filtered for eastward propagation and for the temporal and spatial scales of the tropical intraseasonal oscillations. An independent and simpler compositing method is applied to show that the results of this multiple linear regression model provide better description of the actual relationships between eastward and westward moving intraseasonal modes than a regression model that includes only the linear predictor .

In [2] the application of regression models in macroeconomic analyses is emphasized. The particular situation approached is the influence of final consumption and gross investments on the evolution of Romania's Gross Domestic Product.

\section{Simple ANd Multiple LiNEAR REgRession Model}

A simple linear regression is carried out to estimate the relationship between a dependent variable, $y$, and a single explanatory variable, $\mathrm{x}$, given a set of data that includes observations for both of these variables for a particular population.

Model form is:

$$
y=\beta_{0}+\beta_{1} x+\varepsilon
$$

where $\beta$ 's denote the population regression coefficients, and $\varepsilon$ is a random error.

A multiple linear regression analysis is carried out to predict the values of a dependent variable, $y$, given a set of $\mathrm{k}$ explanatory variables $\left(\mathrm{x}_{1}, \mathrm{x}_{2}, \ldots, \mathrm{x}_{\mathrm{k}}\right)$.

Model form is:

$$
y=\beta_{0}+\beta_{1} x_{1}+\beta_{2} x_{2}+\ldots+\beta_{k} x_{k}+\varepsilon
$$

where $\beta$ 's denote the population regression coefficients, and $\varepsilon$ is a random error.

Excel and SPSS regression computer programs were used to determine the regression coefficients and analyse the data. 


\section{Problem ANd ObJect of Study}

The purpose of this study was to contribute to knowledge relating to the use of simple and multiple linear regression in educational research by establishing an appropriate linear regression model to analyze the relationship between variables as a final grade in the student exam in Mathematics (considered as a dependent or variable $\mathrm{Y}$ ) depending on the 1 st periodical exam and 2 nd periodical exam (considered as independent or predictive $\mathrm{X}$ variables).

The data was collected by a sample of 40 students, 20 of University "Goce Delcev"- Stip (UGD) and 20 from students of "Mother Teresa" University - Skopje (MTU). In order to determine the regression coefficients and to analyze the data, math applicative software was used.

\section{EXCEL ANALYSIS OF DATA FROM MTU}

The equation of the multiple regression model is:

$Y=2.284+3.230 X_{1}-0.436 X_{2}$.

Regression Statistics for the multiple regression model is given in figure1.

The equation of the simple regression model for the $X_{1}$ variable is:

$Y=1.538+2.863 X_{1}$.

Regression Statistics for the simple regression model for the $X_{1}$ variable is given in figure2.

The equation of the simple regression model for $X_{2}$ variable is:

$Y=-1.375+3.131 X_{2}$.

Regression Statistics for the simple regression model for the $X_{2}$ variable is given in figure3.

\section{SPSS ANALYSIS OF DATA FROM MTU}

In figure 4, 5 and 6 are given model summary for the simple regression model for the $X_{1}$ variable, for simple regression model for the $X_{2}$ variable and for multiple regression model respectively with SPSS for MTU.

\section{VI.INTERPRETING THE RESULTS FROM MTU}

From the analysis made using two application softwares we see the same results in the tables obtained. Some individual parameters are interpreted as follows:

The multiple correlation coefficient $(R)$ represents the extent of the relation between the dependent variables and two or more independent variables. The closer to one is, the greater is the connectivity.

In our results we see that $\mathrm{R}>0.93$ in all cases, which means that the correlation between the $\mathrm{Y}$ variable and the $X_{1}$ and $X_{2}$ variables is relatively strong.

The coefficient of determination $\left(R^{2}\right)$ represents the variance of the variables interpreted by the model.

The coefficient of determination serves as a measure of representation of the model. Value $R^{2}>0.87$, therefore it can be said that found linear regression models are representative. Where, as we can see from tables the most representative is the multiple linear regression model.

The statistical significance of the regression model is determined based on the value of the empirical ratio $\mathrm{F}$, i.e. of the corresponding value $\mathrm{p}$ (so-called group test of the importance of the regression model). Where for our case of multiple model is 0.000000000003 , i.e. with the level of risk p <0.01, we claim that at least one of the regression variables has a statistically significant impact on the final grade in Mathematics, respectively, the multiple linear regression model is statistically significant.

In the previous case, the statistical significance of the overall regression model was assessed. The data found in the regression output tables provide information on the statistical significance of the respective regression coefficients (so-called relevant regression model significance test). The statistical significance of the regression coefficients is determined on the basis of t-test i.e., of the corresponding values P. For our cases this value is less than 0.05 so we conclude that in the linear regression models both two variables have an impact of statistical significance on the "final grade in Mathematics" variable. 


\section{SUMMARY \\ OUTPUT}

\begin{tabular}{|c|c|c|c|c|c|c|c|c|}
\hline \multicolumn{2}{|c|}{ Regression Statistics } & & & & & & & \\
\hline Multiple R & 0,9777 & & & & & & & \\
\hline R Square & 0,9559 & & & & & & & \\
\hline \multicolumn{9}{|l|}{ Adjusted R } \\
\hline Square & 0,9507 & & & & & & & \\
\hline \multicolumn{9}{|l|}{ Standard } \\
\hline Error & 3,7763 & & & & & & & \\
\hline Observations & 20,0000 & & & & & & & \\
\hline \multicolumn{9}{|l|}{ ANOVA } \\
\hline & $D f$ & SS & $M S$ & $F$ & Significance $F$ & & & \\
\hline Regression & 2 & 5256,37 & 2628,19 & 184,30 & 0,000000000003 & & & \\
\hline Residual & 17 & 242,43 & 14,26 & & & & & \\
\hline \multirow[t]{3}{*}{ Total } & 19 & 5498,80 & & & & & & \\
\hline & & Standard & & & & Upper & Lower & Upper \\
\hline & Coefficients & Error & t Stat & P-value & Lower 95\% & $95 \%$ & $95,0 \%$ & $95,0 \%$ \\
\hline Intercept & 2,2837 & 2,1351 & 1,0696 & 0,2998 & $-2,2210$ & 6,7884 & $-2,2210$ & 6,7884 \\
\hline X Variable 1 & 3,2300 & 0,5650 & 5,7170 & 0,0000 & 2,0380 & 4,4220 & 2,0380 & 4,4220 \\
\hline X Variable 2 & $-0,4359$ & 0,6469 & $-0,6738$ & 0,5095 & $-1,8007$ & 0,9290 & $-1,8007$ & 0,9290 \\
\hline
\end{tabular}

Fig.1 Regression Statistic for the multiple regression model

\section{SUMMARY}

OUTPUT

\begin{tabular}{lr}
\hline \multicolumn{2}{c}{ Regression Statistics } \\
\hline Multiple R & 0,9771 \\
R Square & 0,9547 \\
Adjusted R & \\
Square & 0,9522 \\
Standard & \\
Error & 3,7186 \\
Observations & 20,0000 \\
\hline
\end{tabular}

ANOVA

\begin{tabular}{lrrrrr}
\hline & Df & \multicolumn{1}{c}{ SS } & \multicolumn{1}{c}{ MS } & \multicolumn{1}{c}{$F$} & Significance $F$ \\
\hline Regression & 1 & 5249,8984 & 5249,8984 & 379,6608 & 0,0000000000002 \\
Residual & 18 & 248,9016 & 13,8279 & & \\
Total & 19 & 5498,8000 & & & \\
\hline
\end{tabular}

\begin{tabular}{lrrrrrrrr}
\hline & Coefficients & $\begin{array}{c}\text { Standard } \\
\text { Error }\end{array}$ & t Stat & P-value & $\begin{array}{r}\text { Lower } \\
95 \%\end{array}$ & $\begin{array}{r}\text { Upper } \\
95 \%\end{array}$ & $\begin{array}{c}\text { Lower } \\
95,0 \%\end{array}$ & $\begin{array}{r}\text { Upper } \\
95,0 \%\end{array}$ \\
\hline & & & & & & & & \\
Intercept & 1,5381 & 1,7980 & 0,8554 & 0,4036 & $-2,2394$ & 5,3155 & 2,2394 & 5,3155 \\
X Variable 1 & 2,8629 & 0,1469 & 19,4849 & 0,0000 & 2,5542 & 3,1715 & 2,5542 & 3,1715 \\
\hline
\end{tabular}

Fig.2 Regression Statistic for the simple regression model for the $X_{1}$ variable 
SUMMARY

OUTPUT

\begin{tabular}{lr}
\hline \multicolumn{2}{c}{ Regression Statistics } \\
\hline Multiple R & 0,9334 \\
R Square & 0,8711 \\
Adjusted R & \\
Square & 0,8640 \\
Standard & \\
Error & 6,2740 \\
Observations & 20,0000 \\
\hline
\end{tabular}

ANOVA

\begin{tabular}{lrrrrr}
\hline & $d f$ & \multicolumn{1}{c}{ SS } & \multicolumn{1}{c}{ MS } & \multicolumn{1}{c}{$F$} & \multicolumn{1}{c}{ Significance $F$} \\
\hline Regression & 1 & 4790,2733 & 4790,2733 & 121,6961 & 0,000000001931 \\
Residual & 18 & 708,5267 & 39,3626 & & \\
Total & 19 & 5498,8000 & & & \\
\hline
\end{tabular}

\begin{tabular}{|c|c|c|c|c|c|c|c|c|}
\hline & & Standard & & & Lower & Upper & Lower & Upper \\
\hline & Coefficients & Error & t Stat & P-value & $95 \%$ & $95 \%$ & $95,0 \%$ & $95,0 \%$ \\
\hline & & & & & & & - & \\
\hline Intercept & $-1,3747$ & 3,3842 & $-0,4062$ & 0,6894 & $-8,4847$ & 5,7353 & 8,4847 & 5,7353 \\
\hline X Variable 2 & 3,1313 & 0,2838 & 11,0316 & 0,0000 & 2,5350 & 3,7277 & 2,5350 & 3,7277 \\
\hline
\end{tabular}

Fig.3 Regression Statistic for the simple regression model for the $X_{2}$ variable

\begin{tabular}{|c|c|c|c|c|}
\hline \multicolumn{5}{|c|}{ Model Summary } \\
\hline Model & $\mathrm{R}$ & R Square & $\begin{array}{l}\text { Adjusted R } \\
\text { Square }\end{array}$ & $\begin{array}{l}\text { Std. Error of the } \\
\text { Estimate }\end{array}$ \\
\hline$\overline{1}$ & $.977^{\mathrm{a}}$ & ,955 & ,952 & 3,71858 \\
\hline
\end{tabular}

a. Predictors: (Constant), $\mathrm{x} 1$

ANOVA $^{\mathrm{a}}$

\begin{tabular}{|ll|r|r|r|r|r|}
\hline Model & & Sum of & Df & Mean Square & F & Sig. \\
\hline 1 & Regression & 5249,898 & 1 & 5249,898 & 379,661 & $.000^{\circ}$ \\
& Residual & 248,902 & 18 & 13,828 & & \\
& Total & 5498,800 & 19 & & & \\
\hline
\end{tabular}

a. Dependent Variable: y

b. Predictors: (Constant), $x 1$

Coefficients $^{\mathrm{a}}$

\begin{tabular}{|c|c|c|c|c|c|c|}
\hline \multirow{2}{*}{\multicolumn{2}{|c|}{ Model }} & \multicolumn{2}{|c|}{ Unstandardized Coefficients } & \multirow{2}{*}{$\begin{array}{c}\begin{array}{c}\text { Standardized } \\
\text { Coefficients }\end{array} \\
\text { Beta } \\
\end{array}$} & \multirow[b]{2}{*}{$\mathrm{t}$} & \multirow[b]{2}{*}{ Sig. } \\
\hline & & $\mathrm{B}$ & Std. Error & & & \\
\hline & $\begin{array}{l}\text { (Constant) } \\
\mathrm{x} 1\end{array}$ & $\begin{array}{l}1,538 \\
2,863\end{array}$ & $\begin{array}{r}1,798 \\
, 147\end{array}$ & ,977 & $\begin{array}{r}, 855 \\
19,485\end{array}$ & $\begin{array}{l}, 404 \\
, 000\end{array}$ \\
\hline
\end{tabular}

a. Dependent Variable: $y$

Fig. 4 Model Summary with SPSS for the simple regression model for the $X_{1}$ variable for MTU 
Model Summary

\begin{tabular}{|l|r|r|r|r|}
\hline Model & $\mathrm{R}$ & R Square & $\begin{array}{c}\text { Adjusted R } \\
\text { Square }\end{array}$ & $\begin{array}{c}\text { Std. Error of the } \\
\text { Estimate }\end{array}$ \\
\hline 1 & $.933^{\mathrm{a}}$ &, 871 &, 864 & 6,27396 \\
\hline
\end{tabular}

a. Predictors: (Constant), $\mathrm{x} 2$

ANOVA $^{\mathrm{a}}$

\begin{tabular}{|ll|r|r|r|r|r|}
\hline Model & & Sum of Squares & df & Mean Square & F & Sig. \\
\hline 1 & Regression & 4790,273 & 1 & 4790,273 & 121,696 & $.000^{\circ}$ \\
& Residual & 708,527 & 18 & 39,363 & & \\
& Total & 5498,800 & 19 & & & \\
\hline
\end{tabular}

a. Dependent Variable: y

b. Predictors: (Constant), x2

\begin{tabular}{|c|c|c|c|c|c|c|}
\hline \multicolumn{7}{|c|}{ Coefficients $^{a}$} \\
\hline \multirow{2}{*}{\multicolumn{2}{|c|}{ Model }} & \multicolumn{2}{|c|}{ Unstandardized Coefficients } & $\begin{array}{c}\text { Standardized } \\
\text { Coefficients }\end{array}$ & \multirow[b]{2}{*}{$\mathrm{t}$} & \multirow[b]{2}{*}{ Sig. } \\
\hline & & $B$ & Std. Error & Beta & & \\
\hline 1 & $\begin{array}{l}\text { (Constant) } \\
x 2\end{array}$ & $\begin{array}{r}-1,375 \\
3,131\end{array}$ & $\begin{array}{r}3,384 \\
, 284\end{array}$ & ,933 & $\begin{array}{r}-, 406 \\
11,032\end{array}$ & $\begin{array}{l}, 689 \\
, 000\end{array}$ \\
\hline
\end{tabular}

a. Dependent Variable: $y$

Fig. 5 Model Summary with SPSS for the simple regression model for the $X_{2}$ variable for MTU

\begin{tabular}{|l|r|r|r|r|}
\hline Model & $\mathrm{R}$ & $\mathrm{R}$ Square & $\begin{array}{c}\text { Adjusted R } \\
\text { Square }\end{array}$ & $\begin{array}{c}\text { Std. Error of the } \\
\text { Estimate }\end{array}$ \\
\hline 1 & $.978^{\mathrm{a}}$ &, 956 &, 951 & 3,77630 \\
\hline
\end{tabular}

a. Predictors: (Constant), x2, x1

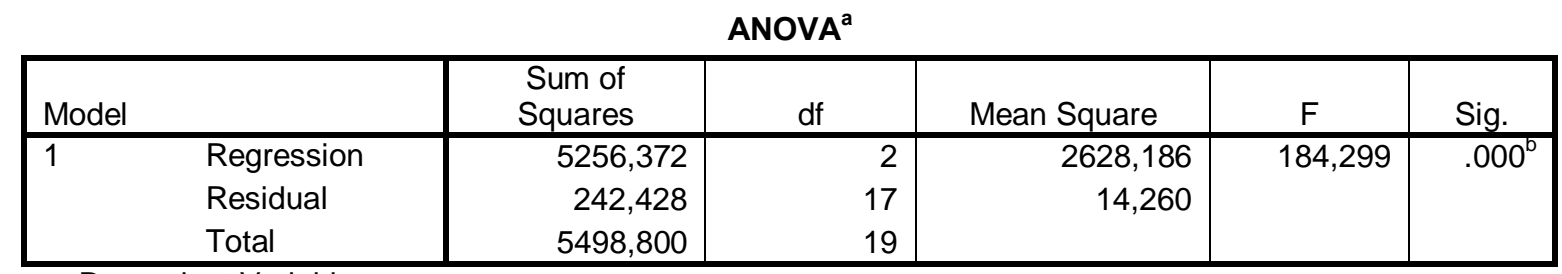

a. Dependent Variable: y

b. Predictors: (Constant), x2, x1

\begin{tabular}{|c|c|c|c|c|c|c|}
\hline \multirow{2}{*}{\multicolumn{2}{|c|}{ Model }} & \multicolumn{2}{|c|}{ Unstandardized Coefficients } & \multirow{2}{*}{$\begin{array}{c}\begin{array}{c}\text { Standardized } \\
\text { Coefficients }\end{array} \\
\text { Beta } \\
\end{array}$} & \multirow[b]{2}{*}{$\mathrm{t}$} & \multirow[b]{2}{*}{ Sig. } \\
\hline & & $\mathrm{B}$ & Std. Error & & & \\
\hline \multirow[t]{3}{*}{1} & (Constant) & 2,284 & 2,135 & & 1,070 & 300 \\
\hline & $\mathrm{x} 1$ & 3,230 &, 565 & 1,102 & 5,717 &, 000 \\
\hline & $x 2$ &,- 436 & ,647 &,- 130 &,- 674 &, 510 \\
\hline
\end{tabular}

a. Dependent Variable: $y$

Fig. 6 Model Summary for the multiple regression model with SPSS for MTU

\section{EXCEL ANALYSIS OF DATA FROM UGD}

The equation of the multiple regression model is

$Y=2.961+1.754 X_{1}+1.243 X_{2}$.

Regression Statistics for the multiple regression model is given in figure 7. 
The equation of the simple regression model for the $X_{1}$ variable is

$Y=6.547+2.673 X_{1}$

Regression Statistics for the simple regression model for the $X_{1}$ variable is given in figure 8 .

The equation of the simple regression model for the $X_{2}$ variable is

$Y=0.947+3.167 X_{2}$.

Regression Statistics for the simple regression model for the $X_{2}$ variable is given in figure 9.

\section{SPSS ANALYSIS OF DATA FROM UGD}

In figure 10, 11 and 12 are given model summary for the simple regression model for the $X_{1}$ variable, for simple regression model for the $X_{2}$ variable and for the multiple regression model respectively with SPSS for U.

\section{IX.INTERPRETING THE RESULTS FROM UGD}

From the analysis made using two application softwares we see the same results in the tables obtained. Individual parameters are interpreted as follows:

The multiple correlation coefficient $(R)$ represents the extent of the relation between the dependent variables and two or more independent variables. The closer to one is, the greater is the connectivity.

In our results we see that $\mathrm{R}>0.94$ in all cases, which means that the correlation between the $\mathrm{Y}$ variable and the $X_{1}$ and $X_{2}$ variables is relatively strong.

The coefficient of determination $\left(R^{2}\right)$ represents the variance of the variables interpreted by the model. The coefficient of determination serves as a measure of representation of the model. Value $R^{2}>0.87$, therefore it can be said that found linear regression models are representative. Where, as we can see from tables the most representative is the multiple linear regression model.

The statistical significance of the regression model is determined based on the value of the empirical ratio $\mathrm{F}$, i.e. of the corresponding value $\mathrm{p}$ (so-called group test of the importance of the regression model). Where for our case of multiple model is 0.0000000000051 , i.e. with the level of risk $\mathrm{p}<0.01$, we claim that at least one of the regression variables has a statistically significant impact on the final grade in Mathematics, respectively, the multiple linear regression model is statistically significant.

In the previous case, the statistical significance of the overall regression model was assessed. The data found in the regression output tables gives us information on the statistical significance of the respective regression coefficients (so-called relevant regression model significance test). The statistical significance of the regression coefficients is determined on the basis of t-test i.e., of the corresponding values P. For our cases this value is less than 0.05 so we conclude that in the linear regression models both two variables have an impact of statistical significance on the "final grade in Mathematics" variable.

\section{Conclusions}

From the analysis above, our multiple regression model as well as simple linear regression models for predicting and analyzing the final grade in Mathematics, Y, from both Universities are useful and adequate.

For further work, we can consider developing and studying similar models in the field of education, social sciences, economics, etc., adding different variables. 
SUMMARY

OUTPUT

\begin{tabular}{lr}
\hline \multicolumn{2}{c}{ Regression Statistics } \\
\hline Multiple R & 0,9762 \\
R Square & 0,9530 \\
Adjusted R & \\
Square & \\
Standard & 0,9475 \\
Error & \\
Observations & 3,7652 \\
\hline
\end{tabular}

ANOVA

\begin{tabular}{lrrrrr}
\hline & Df & \multicolumn{1}{c}{ SS } & \multicolumn{1}{c}{ MS } & \multicolumn{1}{c}{$F$} & \multicolumn{1}{c}{ Significance $F$} \\
\hline Regression & 2 & 4891,5431 & 2445,7715 & 172,5183 & 0,0000000000051 \\
Residual & 17 & 241,0069 & 14,1769 & & \\
Total & 19 & 5132,5500 & & & \\
\hline
\end{tabular}

\begin{tabular}{lrcrrrrrr}
\hline & Coefficients & $\begin{array}{c}\text { Standard } \\
\text { Error }\end{array}$ & t Stat & P-value & Lower 95\% & $\begin{array}{c}\text { Upper } \\
95 \%\end{array}$ & $\begin{array}{c}\text { Lower } \\
95,0 \%\end{array}$ & $\begin{array}{c}\text { Upper } \\
95,0 \%\end{array}$ \\
\hline & & & & & & & & \\
Intercept & 2,9606 & 2,1305 & 1,3897 & 0,1826 & $-1,5343$ & 7,4555 & 1,5343 & 7,4555 \\
X Variable 1 & 1,7538 & 0,3360 & 5,2195 & 0,0001 & 1,0449 & 2,4627 & 1,0449 & 2,4627 \\
X Variable 2 & 1,2429 & 0,4092 & 3,0375 & 0,0074 & 0,3796 & 2,1063 & 0,3796 & 2,1063 \\
\hline
\end{tabular}

Fig. 7 Regression Statistics for the multiple regression model

\section{SUMMARY \\ OUTPUT}

\begin{tabular}{lr}
\hline \multicolumn{2}{c}{ Regression Statistics } \\
\hline Multiple R & 0,9631 \\
R Square & 0,9276 \\
Adjusted R & \\
Square & 0,9235 \\
Standard & \\
Error & 4,5449 \\
Observations & 20,0000 \\
\hline
\end{tabular}

\begin{tabular}{|c|c|c|c|c|c|}
\hline & $D f$ & SS & MS & $F$ & Significance $F$ \\
\hline Regression & 1 & 4760,7397 & 4760,7397 & 230,4759 & 0,000000000011 \\
\hline Residual & 18 & 371,8103 & 20,6561 & & \\
\hline Total & 19 & 5132,5500 & & & \\
\hline
\end{tabular}

\begin{tabular}{lrrrrrrrr}
\hline & \multicolumn{3}{c}{ Standard } & & Lower & Upper & Lower & Upper \\
& Coefficients & Error & t Stat & P-value & $95 \%$ & $95 \%$ & $95,0 \%$ & $95,0 \%$ \\
\hline Intercept & 6,5465 & 2,1407 & 3,0581 & 0,0068 & 2,0491 & 11,0440 & 2,0491 & 11,0440 \\
X Variable 1 & 2,6732 & 0,1761 & 15,1814 & 0,0000 & 2,3033 & 3,0432 & 2,3033 & 3,0432 \\
\hline
\end{tabular}

Fig. 8 Regression Statistics for the simple regression model for the $X_{1}$ variable 


\section{SUMMARY OUTPUT}

\begin{tabular}{lr}
\hline \multicolumn{2}{c}{ Regression Statistics } \\
\hline Multiple R & 0,9369 \\
R Square & 0,8778 \\
Adjusted R & \\
Square & 0,8710 \\
Standard & \\
Error & 5,9030 \\
Observations & 20,0000 \\
\hline
\end{tabular}

\begin{tabular}{|c|c|c|c|c|c|}
\hline & $D f$ & SS & $M S$ & $F$ & Significance $F$ \\
\hline Regression & 1 & 4505,3223 & 4505,3223 & 129,2924 & 0,000000001195 \\
\hline Residual & 18 & 627,2277 & 34,8460 & & \\
\hline Total & 19 & 5132,5500 & & & \\
\hline
\end{tabular}

\begin{tabular}{lrrrrrrrrr}
\hline & \multicolumn{3}{c}{$\begin{array}{c}\text { Standard } \\
\text { Error }\end{array}$} & t Stat & P-value & $\begin{array}{c}\text { Lower } \\
95 \%\end{array}$ & $\begin{array}{c}\text { Upper } \\
95 \%\end{array}$ & $\begin{array}{c}\text { Lower } \\
95,0 \%\end{array}$ & $\begin{array}{r}\text { Upper } \\
95,0 \%\end{array}$ \\
\hline & & & & & & & & \\
& & & & & & & & \\
Intercept & 0,9468 & 3,2849 & 0,2882 & 0,7765 & & $-5,9545$ & 7,8481 & 5,9545 & 7,8481 \\
X Variable 2 & 3,1670 & 0,2785 & 11,3707 & 0,0000 & 2,5818 & 3,7521 & 2,5818 & 3,7521 \\
\hline
\end{tabular}

Fig. 9 Regression Statistics for the simple regression model for the $X_{2}$ variable

Model Summary

\begin{tabular}{|c|c|c|c|c|}
\hline Model & $\mathrm{R}$ & R Square & $\begin{array}{l}\text { Adjusted R } \\
\text { Square }\end{array}$ & $\begin{array}{c}\text { Std. Error of the } \\
\text { Estimate }\end{array}$ \\
\hline 1 & $.963^{a}$ & ,928 & ,924 & 4,54490 \\
\hline
\end{tabular}

a. Predictors: (Constant), $\mathrm{x} 1$

ANOVA $^{\mathrm{a}}$

\begin{tabular}{|rl|r|r|r|r|r|}
\hline & & & & & \\
Model & & Sum of Squares & df & Mean Square & F & Sig. \\
\hline 1 & Regression & 4760,740 & 1 & 4760,740 & 230,476 & $.000^{\mathrm{b}}$ \\
& Residual & 371,810 & 18 & 20,656 & & \\
& Total & 5132,550 & 19 & & & \\
\hline
\end{tabular}

a. Dependent Variable: $y$

b. Predictors: (Constant), x1

Coefficients $^{\mathrm{a}}$

\begin{tabular}{|c|c|c|c|c|c|c|}
\hline \multirow{2}{*}{\multicolumn{2}{|c|}{ Model }} & \multicolumn{2}{|c|}{ Unstandardized Coefficients } & \multirow{2}{*}{$\begin{array}{c}\begin{array}{c}\text { Standardized } \\
\text { Coefficients }\end{array} \\
\text { Beta }\end{array}$} & \multirow[b]{2}{*}{$\mathrm{t}$} & \multirow[b]{2}{*}{ Sig. } \\
\hline & & $\mathrm{B}$ & Std. Error & & & \\
\hline & (Constant) & 6,547 & 2,141 & & 3,058 & ,007 \\
\hline & $\mathrm{x} 1$ & 2,673 & 176 & ,963 & 15,181 &, 000 \\
\hline
\end{tabular}

a. Dependent Variable: $y$

Fig. 10 Model Summary with SPSS for the simple regression model for the $X_{1}$ variable 
Model Summary

\begin{tabular}{|c|c|c|c|c|}
\hline Model & $\mathrm{R}$ & R Square & $\begin{array}{c}\text { Adjusted R } \\
\text { Square }\end{array}$ & $\begin{array}{l}\text { Std. Error of the } \\
\text { Estimate }\end{array}$ \\
\hline 1 & $.937^{a}$ & ,878 & ,871 & 5,90305 \\
\hline
\end{tabular}

a. Predictors: (Constant), $\mathrm{x} 2$

ANOVA $^{\mathrm{a}}$

\begin{tabular}{|ll|r|r|r|r|r|}
\hline Model & & Sum of Squares & Df & Mean Square & F & Sig. \\
\hline 1 & Regression & 4505,322 & 1 & 4505,322 & 129,292 & $.000^{\mathrm{b}}$ \\
& Residual & 627,228 & 18 & 34,846 & & \\
& Total & 5132,550 & 19 & & & \\
\hline
\end{tabular}

a. Dependent Variable: $y$

b. Predictors: (Constant), x2

Coefficients $^{\mathrm{a}}$

\begin{tabular}{|c|c|c|c|c|c|c|}
\hline \multirow{2}{*}{\multicolumn{2}{|c|}{ Model }} & \multicolumn{2}{|c|}{ Unstandardized Coefficients } & \multirow{2}{*}{$\begin{array}{c}\begin{array}{c}\text { Standardized } \\
\text { Coefficients }\end{array} \\
\text { Beta }\end{array}$} & \multirow[b]{2}{*}{$\mathrm{t}$} & \multirow[b]{2}{*}{ Sig. } \\
\hline & & $\mathrm{B}$ & Std. Error & & & \\
\hline & $\begin{array}{l}\text { (Constant) } \\
x 2\end{array}$ & $\begin{array}{r}, 947 \\
3,167\end{array}$ & $\begin{array}{r}3,285 \\
, 279\end{array}$ & ,937 & $\begin{array}{r}, 288 \\
11,371\end{array}$ & $\begin{array}{l}, 776 \\
, 000\end{array}$ \\
\hline
\end{tabular}

a. Dependent Variable: $y$

Fig. 11 Model Summary with SPSS for the simple regression model for the $X_{2}$ variable for UGD

Model Summary

\begin{tabular}{|l|r|r|r|r|}
\hline Model & $\mathrm{R}$ & R Square & $\begin{array}{c}\text { Adjusted R } \\
\text { Square }\end{array}$ & $\begin{array}{c}\text { Std. Error of the } \\
\text { Estimate }\end{array}$ \\
\hline 1 & $.976^{\mathrm{a}}$ &, 953 &, 948 & 3,76522 \\
\hline
\end{tabular}

a. Predictors: (Constant), $\mathrm{x} 2, \mathrm{x} 1$

ANOVA $^{\mathrm{a}}$

\begin{tabular}{|rl|r|r|r|r|r|}
\hline Model & & Sum of Squares & df & Mean Square & F & Sig. \\
\hline 1 & Regression & 4891,543 & 2 & 2445,772 & 172,518 & $.000^{b}$ \\
& Residual & 241,007 & 17 & 14,177 & & \\
& Total & 5132,550 & 19 & & & \\
\hline
\end{tabular}

a. Dependent Variable: $y$

b. Predictors: (Constant), x2, x1

Coefficients $^{\mathrm{a}}$

\begin{tabular}{|c|c|c|c|c|c|c|}
\hline \multirow{2}{*}{ Mode } & & \multicolumn{2}{|c|}{ Unstandardized Coefficients } & \multirow{2}{*}{$\begin{array}{c}\begin{array}{c}\text { Standardized } \\
\text { Coefficients }\end{array} \\
\text { Beta }\end{array}$} & \multirow[b]{2}{*}{$\mathrm{t}$} & \multirow[b]{2}{*}{ Sig. } \\
\hline & & $\mathrm{B}$ & Std. Error & & & \\
\hline \multirow[t]{3}{*}{1} & (Constant) & 2,961 & 2,130 & & 1,390 &, 183 \\
\hline & $\mathrm{x} 1$ & 1,754 & ,336 & ,632 & 5,219 & ,000 \\
\hline & $\mathrm{x} 2$ & 1,243 & ,409 & ,368 & 3,038 & ,007 \\
\hline
\end{tabular}

a. Dependent Variable: $y$

Fig. 12 Model Summary with SPSS for for the multiple regression model for UGD 


\section{REFERENCES}

[1] C. Anghelache, M.G. Anghel, L. Prodan, C. Sacală and M. Popovici, Multiple Linear Regression Model Used in Economic Analyses, Romanian Statistical Review Supplement, Vol. 62. Issue 10, pp. 120-127, (October), 2014

[2] C. Anghelache, A. Manole and M. G. Anghel, Analysis of final consumption and gross investment influence on GDP - multiple linear regression model, Theoretical and Applied Economics, Volume XXII No. 3(604), pp. 137-142, 2015

[3] A.C Cameron, and P.K Trivedi, Regression Analysis of Cout Data, Cambridge, 1998.

[4] F. Hoxha, Metoda të analizës numerike, Tiranë, 2008.

[5] D. Jaksimovic, Zbirka Zadataka iz poslovne statistike, Beograd, 2004.

[6] Sh. Leka, Teoria e probabiliteteve dhe statistika matematike, Tiranë, 2004.

[7] J. T. McClove, P. George Benson, Terry Sincich, Statistics for Business and Economics, USA, 1998.

[8] M. Papiq, Statistika e aplikuar në MS EXEL, Prishtinë, 2007.

[9] L. Puka, Probabliliteti dhe Statistika e zbatuar, Tiranë, 2010.

[10] J. M. Rojo, Regresion lineal multiple, Madrid, 2007.

[11] P. E. Roundy and W. M. Frank, Applications of a Multiple Linear Regression Model to the Analysis of Relationships between Eastward and Westward Moving Intraseasonal Modes, Journal of the atmospheric sciences, pp. 3041-3048, 2004

[12] M. Shakil, A multiple Linear regression Model to Predict the Student's Final Grade in a Mathematics Class,

[13] A. F. Siegel, Pratical Statistics, USA, 1996.

[14] D. S. Wilks, Statistical Methods in the Atmospheric Sciences: An Introduction, International Geophysical Series, Vol. 59, Academic Press, pp. 467, 1995

Appendix

\begin{tabular}{|c|c|c|}
\hline $\begin{array}{c}\text { Scores of final exam } \\
\qquad \begin{array}{c}(60) \\
\text { MTU }\end{array}\end{array}$ & $\begin{array}{c}\text { Scores of lst periodical exam } \\
(20) \\
\text { MTU }\end{array}$ & $\begin{array}{c}\text { Scores of } 2^{\text {nd }} \text { periodical exam } \\
\text { (20) } \\
\text { MTU }\end{array}$ \\
\hline$Y$ & $X_{1}$ & $X_{2}$ \\
\hline 60 & 20 & 19 \\
\hline 45 & 15 & 13 \\
\hline 55 & 18 & 15 \\
\hline 30 & 9 & 10 \\
\hline 14 & 5 & 6 \\
\hline 33 & 10 & 11 \\
\hline 44 & 15 & 13 \\
\hline 10 & 3 & 4 \\
\hline 25 & 8 & 10 \\
\hline 57 & 20 & 19 \\
\hline 42 & 16 & 14 \\
\hline 27 & 8 & 7 \\
\hline 15 & 9 & 12 \\
\hline 50 & 16 & 17 \\
\hline 17 & 4 & 6 \\
\hline 22 & 7 & 8 \\
\hline 48 & 16 & 15 \\
\hline 39 & 12 & 13 \\
\hline 7 & 2 & 2 \\
\hline 12 & 4 & 3 \\
\hline
\end{tabular}

Fig. 13 Appendix with Data for MTU 


\begin{tabular}{|c|c|c|}
\hline $\begin{array}{l}\text { Scores of final exam } \\
\qquad \begin{array}{c}(60) \\
\text { UGD }\end{array}\end{array}$ & $\begin{array}{l}\text { Sores of ls periodical exam } \\
\text { (20) } \\
\text { UGD }\end{array}$ & $\begin{array}{c}\text { Soces of } 2^{2} \text { periodical exam } \\
\text { (20) } \\
\text { UGD }\end{array}$ \\
\hline$Y$ & $X_{1}$ & $X_{2}$ \\
\hline 58 & 19 & 19 \\
\hline 55 & 17 & 18 \\
\hline 49 & 15 & 11 \\
\hline 40 & 10 & 12 \\
\hline 29 & 7 & 7 \\
\hline 37 & 10 & 11 \\
\hline 39 & 9 & 13 \\
\hline 21 & 6 & 8 \\
\hline 16 & 5 & 7 \\
\hline 56 & 20 & 17 \\
\hline 20 & 5 & 9 \\
\hline 29 & 12 & 8 \\
\hline 18 & 6 & 5 \\
\hline 15 & 4 & 5 \\
\hline 10 & 2 & 4 \\
\hline 25 & 7 & 10 \\
\hline 54 & 16 & 15 \\
\hline 49 & 18 & 13 \\
\hline 24 & 6 & 5 \\
\hline 59 & 20 & 19 \\
\hline
\end{tabular}

Fig. 14 Appendix with Data for UGD 